Prace Literackie LVIII

Wrocław 2018

https://doi.org/10.19195/0079-4767.58.9

MAŁGORZATA KRAKOWIAK

ORCID: 0000-0002-5223-2626

Uniwersytet Śląski w Katowicach

\title{
Suma czy różnica, czyli kto jest polskim patriotą? Rozważania wokół kulturowych mitów współczesności
}

— Gdyby ktoś mnie zapytał, czym jest dla mnie Polska, odpowiedziałbym, że językiem i bogactwem ludzkich losów.

— To jest patriotyczne podejście?

— Niech sam pan z tego wyciągnie wnioski. Nie lubię słowa patriotyzm, jest nieprawdopodobnie zużyte. To jest najbardziej chore słowo w polszczyźnie ${ }^{1}$.

Przed stu laty Polska powróciła na mapy Europy. Towarzyszące obchodom rocznicy odzyskania niepodległości wydarzenia — skromne i okazałe, lepsze i gorsze, przemyślane i takie, w których trudno dojrzeć myśl przewodnią — skłaniają do namysłu tudzież do rekapitulacji poglądów na temat polskiego patriotyzmu, a dokładniej tego, kto się mieni (i na jakiej podstawie) polskim patriotą i kto za takiego bywa uznawany. Przed kilkunastu laty Władysław Stróżewski celnie zauważał:

Pojęcie patriotyzmu, jak również współkonstytuujące je pojęcie ojczyzny (wszak patriotyzm zdefiniować najprościej jako amor patriae), różne w naszym kraju przechodziły koleje. Był czas, kiedy wysuwały się na plan pierwszy, wyciskając łzy rozpaczy lub budząc nieśmiałą nadzieję ${ }^{2}$.

O słuszności tej obserwacji nie trzeba przekonywać. Na prawach skrzydlatego słowa unosi się do dziś Norwidowa fraza: „Że Ojczyzna jest to wielki — zbio-

${ }^{1}$ W. Myśliwski, Wbrew rozsądkowi i nadziei. Z Wiesławem Myśliwskim rozmawia M. Nogaś, „Wyborcza. Książki. Magazyn do czytania”, listopad 2018, s. 22.

2 W. Stróżewski, Patriotyzm, czyli przemienieni kołodzieje, „Tygodnik Powszechny”, wydanie specjalne 2018, nr 2, s. 98. Prwdr. „Tygodnik Powszechny” 2006, nr 27. 
rowy - Obowiązek"3. Wczytując się w nią, można domniemywać, że zarówno ojczyzna, jak i żywione ku niej uczucia są/winny być wspólnotowe, sumujące, a nie wykluczające, odejmujące prawa, różnicujące. Norwid kontynuował swą myśl następująco:

Że Obywatele Ojczyznę składający dzielą się samą naturą rzeczy — bez żadnego prawa nałożonego z góry (bo tego być nie może) - na:

(1) służących Ojczyźnie przez s i e b i e, przez człowieka swojego...

i (2) na służących człowiekowi przez Ojczyznę, bo taki organizm w naturze rzeczy jest - i nie są to kasty — ani stopnie sztuczne - ale prawo wrodzone — natura-rerum ${ }^{4}$.

Etyczny fundament tych słów nie pozwala wątpić w słuszność naszej uprzedniej domniemywanej interpretacji. Jednocześnie wszak zdajemy sobie sprawę ze skrajnego idealizmu ukutego przez Norwida aksjomatu: tak być powinno, ale myślenie o ojczyźnie jako zbiorowym obowiązku jest trudne, a zawsze wspólne działanie według każdorazowo tożsamych reguł zgoła niemożliwe, a raczej zawsze hierarchizujące, wykluczające, różnicujące właśnie.

Owe „odśrodkowe” tendencje społeczne równoważone są przez — paradoksalną nieco — potrzebę jedności, doświadczania jednolitej, zbiorowej tożsamości. Taka tendencja wyraźnie rysuje się w kulturologicznej refleksji nad współczesnością. Zbigniew Mikołejko powiada:

Po latach rozchwiania, latach panowania kultury permisywnej i ponowoczesnej z jej „płynnością", o której pisał Zygmunt Bauman, pojawiły się nostalgia, nowe tęsknoty za światem mocniej uładzonym, trwalszym systemem wartości i porządkiem etycznym, wspólnotą5.

Pomocne w zagospodarowywaniu przestrzeni tejże nostalgii — ba! niezbędne nawet - są swoiste elementy składowe polskiego kodu kulturowego, badane przeze mnie ostatnimi czasy kulturowe mity współczesności, rozumiane jako zespoły emblematycznych znaczeń, które pozwalają danej społeczności się wyodrębniać i integrować. Nie są to mity w rozumieniu opowieści, które tłumaczyłyby powstanie świata i człowieka, przyczynę i cel owego zaistnienia, ale raczej hasła wywoławcze, składniki kodu, za pomocą którego komunikują się członkowie społeczeństwa w określonym miejscu i czasie ${ }^{6}$.

${ }^{3}$ C.K. Norwid, Memoriat o młodej emigracji. W odpowiedzi na zapytanie szanownego p. Gatęzowskiego, [w:] idem, Pisma wybrane, t. 4. Proza, Warszawa 1983, s. 394.

${ }^{4}$ Ibidem.

5 Z. Mikołejko, Plutony różańca, [rozm. A. Sowa], „Polityka” 2018, nr 40, s. 31.

${ }^{6}$ Podkreślenia wymaga wieloznaczność słowa „mit” i mnogość kontekstów, w jakich pojawia się ono ostatnimi czasy. W popularnych i popularnonaukowych obiegach rozumiane bywa często jako opowieść nieweryfikowalna, sensacyjna. Przeciwstawia się ją wówczas 'udokumentowanej historii’. W kontekście podjętego tematu polskiego patriotyzmu warto przykładowo wskazać książkę Mity polskie Jarosława Molendy, we wstępie do której autor pisze, by zafrapować potencjalnego czytelnika: „Niezwykła i porażająca jest potęga mitu. [...] Historycy starają się oddzielać mity od rzeczywistości, a mimo to istnieją utarte twierdzenia, które wszyscy mniej lub bardziej biorą za pewnik. [...] W tradycyjnej historiografii raczej przeciwstawiano historię mitowi, twierdząc, że zadaniem naukowego dziejopisarstwa jest uwolnienie się od wszelkich mitów. Zakres tego pojęcia 
Pragnę tu zwrócić uwagę na dwa spośród nich; dwa hasła, będące zarazem aksjologicznymi triadami. Są to: „Bóg - Honor - Ojczyzna” oraz „wolność — równość - braterstwo". Wspólnie tworzą one podstawowe, jak się wydaje, składniki polskiego imaginarium. Kategorię tę przywołałam za Andrzejem Lederem, który wyjaśnia:

Dzięki temu, że historie tworzące imaginarium są reprezentowane w słowach, opowieściach, całej symbolicznej spuściźnie wchłanianej przez każdego z nas — w rodzinie, szkole, kulturze masowej - mogą one jednocześnie stanowić szkielet podmiotowości całej wspólnoty. [...] Imaginarium składa się więc z wyobrażeń połączonych z emocjami i osadzonych w etycznej ramie; wyobrażeń pozwalających przeżywać pewne historie, będące realizacją skrytych marzeń ${ }^{7}$.

Proponując przyjrzenie się wybranym mitom, stanowiącym — powtórzę triady aksjologiczne, już na wstępie należy odnotować próby rozmaitego separowania poszczególnych wartości. Pochylmy się więc na początek nad najbardziej bodaj odpowiadającym rozważaniom o patriotyzmie mitem.

„Bóg - Honor - Ojczyzna” — obecnie to właśnie hasło wydaje się podstawowym emblematem postawy patriotycznej, obok godła i barw narodowych; znakiem i zawołaniem towarzyszącym, wydawałoby się, polskim patriotom „od zawsze". Ilu spośród odwołujących się do niego bądź skandujących je uświadamia sobie jego pochodzenie i prymarny kontekst? To, że stanowiło ono dewizę wojska polskiego na mocy dekretu prezydenta Rzeczypospolitej Polskiej z 15 października 1943 roku (godność tę sprawował wtedy na uchodźstwie Władysław Raczkiewicz). W październiku 1943 roku zadekretowano również oficjalny kanon interpretacji: „Ojczyźnie wszystko prócz miłości Boga najwyższego i honoru”. A wcześniej? Wcześniej w przestrzeni wojskowej i publicznej funkcjonowało hasło „Honor i Ojczyzna”, czyli zawołanie wojska obywatelskiego z czasów napoleońskich, przejęte od francuskiej Legii Honorowej. W pojałtańskiej rzeczywistości hasło „Bóg - Honor - Ojczyzna”, wyparte z przestrzeni publicznej (dla porządku: dewizą Ludowego Wojska Polskiego od 1955 roku było hasło kompletnie niespełniające reguł jakobsonowskiej funkcji poetyckiej „Za naszą ojczy-

został znacząco rozszerzony przez historiografię nowoczesną, która uważa je za szczególną formę świadomości społecznej, element ludzkiej kultury. [...] Mity polskie stanowią próbę odkłamania pewnych obiegowych prawd, do których Polacy tak bardzo się przyzwyczaili. Walka z mitami nie jest prosta, co przyznawał nawet Napoleon, który twierdził, że łatwiej zwyciężyć w dziesięciu bitwach, niż pokonać jeden mit. Książka ta nie jest podręcznikiem historii Polski ani próbą napisania jej od nowa. To rodzaj podsumowania dotychczasowego stanu badań, wzbogaconego o najnowsze hipotezy i wnioski" - idem, Mity polskie, Warszawa 2016, s. 9-10, 13-14. W innych ujęciach badawczych, zyskujących w ostatnich latach uznanie, mit traktowany jest jako odmiana legendy miejskiej, zgoła jako synonim plotki. Zob. M. Napiórkowski, Mitologia współczesna. Relacje o poczynaniach i przygodach krajowców zamieszkałych globalnej wiosce, Warszawa 2013. Wskazywana przeze mnie kategoria kulturowych mitów współczesności oznacza z kolei elementy uzyskane w wyniku synchronicznego opisu stanu zachowań społecznych i pozwalające na pogłębioną analizę stanu społecznej świadomości kulturowej.

${ }^{7}$ A. Leder, Prześniona rewolucja. Ćwiczenie z logiki historycznej, Warszawa 2014, s. 12-13. 
znę PRL"), zyskiwało walor szczególnie cennego elementu kultury odbieranej, poddawanej represjom; istniejącej w pamięci i przestrzeni wspólnotowego mitu właśnie. Dopiero 19 lutego 1993 roku przyjęto ustawę o znakach sił zbrojnych Rzeczypospolitej Polskiej, na mocy której dewizą wojskową stało się na powrót „Bóg - Honor - Ojczyzna”.

Czy przypomnienie proweniencji hasła ma znaczenie? Dla jego współczesnych użytkowników — niewielkie. „Bóg - Honor - Ojczyzna” dlatego właśnie stało się kulturowym mitem współczesności, że traktowane jest ponad- lub pozahistorycznie, że stanowi zbitkę pojęć wielkich, ale percypowanych bez nadmiernego rozważania złożoności implikowanych przez nie desygnatów. O potędze dwóch pierwszych składników w powszechnym odbiorze wiadomo, że... jest. Trudno przecież wyrazić słowami to, co sakralne, najważniejsze, odnoszące się do poczucia ludzkiej godności. Bezzasadne również (a raczej przede wszystkim) byłoby zadawanie podstawowego pytania: czy TY wierzysz w Boga? Mogłoby się bowiem okazać, że MY nie jest monolitem, a przecież o wspólnotę i jedność ma tutaj chodzić. W wersji łagodniejszej ma chodzić o sumę zebraną także z tych w różnym stopniu wątpiących. W warunkach bojowych wszak w sposób naturalny konieczne staje się schematyzowanie, upraszczanie rzeczywistości.

Być może trzeci ze składników hasła - Ojczyzna - będzie zatem czynnikiem łączącym ludzi bez zastrzeżeń; bez zastrzeżeń jednoczącym patriotów? Warto poszukać argumentów, a nie będzie to trudne zadanie. Już sama literatura polska zawiera przecież „nieprzebrane bogactwo” utworów poświęconych Ojczyźnie i świadczących o żywym zainteresowaniu jej sprawami, o miłości do niej. W tym miejscu każdy dostrzeże moje osuwanie się w przestrzeń komunału.

Dla ratunku zatem, wzorem cytowanego na początku niniejszych rozważań Stróżewskiego, sięgam po XXXV epigramat Słowackiego:

Szli krzycząc: „Polska! Polska!” — wtem jednego razu

Chcąc krzyczeć zapomnieli na ustach wyrazu;

Pewni jednak, ze Pan Bóg do synów się przyzna,

Szli dalej krzycząc: „Boże! ojczyzna! ojczyzna”.

Wtem Bóg z Mojżeszowego pokazał się krzaka,

Spojrzał na te krzyczące i zapytał: „Jaka?”

I raptem okazuje się, że nawet „pewniak” — wieszcz narodowy — niczego nie ułatwi, a jedynie pomnoży wątpliwości polskiego patrioty. Czyżby dopuszczalne były różne patriae i różne modele patriotyzmu?! Owszem, jest to nasz polski „kłopot” o bardzo długiej i dobrze udokumentowanej historii. Nawet gdy ograniczymy się — rocznicowo — do ostatniego stulecia, uzyskamy reprezentatywną próbę tego zagadnienia.

Dowodzi tego już sam „wybuch Polski” w 1918 roku i jego artystyczna recepcja. Pominąć tu można przypominanie niejasnych początków i wielu warian-

${ }^{8}$ J. Słowacki, Wiersze i poematy, Warszawa 1988, s. 99-100. 
tów ulubionej ponoć pieśni Józefa Piłsudskiego - Marszu Pierwszej Brygady — kwestii tego, kto jest autorem których jej słów: Tadeusz Biernacki czy Andrzej Hałaciński, i tego, jakie rozgoryczenie legionistów zgoła niepatriotyczną postawą współobywateli dokumentuje choćby taka jej zwrotka:

Nie chcemy już od was uznania,
Ni waszych mów, ni waszych łez.
Skończyły się dni kołatania
Do waszych serc, do waszych kies

(przy czym ostatni wers miał w wykonaniu niektórych żołnierzy nieoficjalną, bardziej dosadną i niepozostawiającą cienia wątpliwości odnośnie do różnic polskich postaw wersję „Do waszych serc, j...ł was pies”).

Wystarczy zebrać garść cytatów z wczesnych wierszy skamandryckich, aby udowodnić antytyrtejskość nastrojów poetyckiej młodzieży, wzorem Słonimskiego „zrzucającej z ramion płaszcz Konrada”, z Wierzyńskim „tańczącej tango na pomnikach" ${ }^{10}$ i z Lechoniem pragnącej oglądać wreszcie tylko wiosnę, a nie Polskę. Owa beztroska szybko przeminęła, a właściwie nigdy nie miała absolutnego charakteru. Żeby się o tym przekonać, czasami wystarczy po prostu nie wyrywać cytatów z kontekstu, by akuratnie przykroić je do założonej tezy. Wszak słynny, miejscami futurystyczno-burzycielski wiersz Herostrates Jana Lechonia (podówczas osiemnastolatka) zamyka zwrotka:

Bo w nocy spać nie mogę i we dnie się trudzę

Myślami, co mi w serce wrastają zwątpieniem,

I chciałbym raz zobaczyć, gdy przeszłość wyżeniem,

Czy wszystko w pył rozkruszę, czy... Polskę obudzę ${ }^{11}$.

Oto rewolucyjny zapał młodzieńca, który pragnąc uwolnić się od śladów, znaków, symboli wszechobecnej polskości, „rozbija się” o polskość właśnie. Nawet gdy dokonam dzieła zniszczenia pamiątek przeszłości, i tak nie uwolnię się od tego, co tworzy moją istotę; albo może wówczas dotrę do istoty, do prawdziwego kształtu tego, co mnie stanowi, a więc do Polski — zdaje się mówić bohater liryczny. Okazuje się, że czymś na kształt osobliwości początkowej ${ }^{12}$ jest dla poety zawsze Polska, mimo że chwilowo nie trzeba za nią umierać. Raptem

${ }^{9}$ Parafraza fragmentu poematu Czarna wiosna (1919) Antoniego Słonimskiego: „Ojczyzna moja wolna, wolna.../Więc zrzucam z ramion płaszcz Konrada./Ojczyzna w więzach już nie biada/ Dźwiga się, wznosi, wstaje wolna".

${ }^{10}$ Parafraza fragmentu Manifestu szalonego z tomu Wróble na dachu (1921) Kazimierza Wierzyńskiego: „Literatura kona w dzikich krzyk/A tłum się śmieje, śmieje do rozpuku!/Kpy jakieś tango tańczą na pomnikach/I wieszczom wrzeszczą: terefere kuku!".

11 J. Lechoń, Poezje, Wrocław-Warszawa-Kraków 1990, s. 5.

12 Użyłam tutaj porównania do terminu występującego w modelach kosmologicznych. Warto zatem zacytować specjalistę: „Początkową osobliwość można uznać za matematyczny odpowiednik Wielkiego Wybuchu. [...] Jeżeli kryterium występowania osobliwości jest urywanie się historii cząstek lub obserwatorów, to o naturze osobliwości nie wiemy nic ponad to, że na niej kończy się nasza wiedza" - M. Heller, Ostateczne wyjaśnienia wszechświata, Kraków 2008, s. 207, 211. 
okazuje się, że autor Herostratesa może być postrzegany nie tyle jako lekkoduch bez estymy, składający wiersz przeciwko przytłaczającej i wszechobecnej ojczyźnie, ile jako ten, który reprezentuje pogłębione intelektualnie nią zainteresowanie, a zatem przedstawiciel zwolenników krytycznego modelu patriotyzmu.

Czy pokój po zakończeniu pierwszej wojny światowej sprzyjał wykształceniu się modeli patriotyzmu „cywilnego”, pokojowego, być może „spokojniejszego" modelu minimalistycznego — polegającego na pracy dla ojczyzny? Nie, ponieważ dominującym wzorem organizowania życia narodów europejskich był jedyny znany im model — wojenny. Jerzy Stempowski trafnie go opisał, używając $\mathrm{w}$ tym celu metafory oblężonego miasta ${ }^{13}$. Moralność oblężeniowa, która każe wynosić potęgę zbiorowości ponad wszystko, była jednym z symptomów katastrofizmu lat trzydziestych ${ }^{14}$.

Co pisywali zatem wówczas tak radośni i lekceważący wszystko skamandryci? Wystarczy otworzyć tomik Kazimierza Wierzyńskiego Wolność tragiczna z 1936 roku, by przekonać się, że widoczny na początku drogi poetyckiej Lechonia w jego wierszach krytyczny model patriotyzmu teraz przybiera formę mniej drapieżną, za to bardziej dramatyczną i zawierającą (właściwą raczej patriotyzmowi ofiarniczemu, heroicznemu) pełnię odpowiedzialnej troski. Ojczyzna chochołów kończy się słowami:

Starym herbem sarmackim w popuszczane pasy

Zatkaj gęby krzyczące i zgłodniałe usta -

I komu teraz jeszcze otuchy za mało,

I przeszłość jesionowa praojców nieśliczna,

Niech stanie pod cokołem i porwany chwałą

Tworzy wolność.

Masz rację. Jakże jest tragiczna! ${ }^{15}$

${ }^{13}$ Sytuację oblężenia mentalnego, moralnego i społeczno-politycznego Stempowski analizował i ukazywał wielokrotnie w esejach z połowy lat trzydziestych i późniejszych. W Nowych marzeniach samotnego wędrowca z 1935 roku czytamy: „Dwadzieścia lat temu wszystkie kraje wojujące stały się obozami warownymi, w których całe życie podporządkowało się domniemanym wymaganiom wojny. System moralności pokojowej ustąpił miejsca moralności wojennej, opartej na śmiałości i sprycie, w której jako summum bonum znajduje się możność swobodnego wykonywania przemocy i cała reszta sprowadza się do cnót taktycznych, w mniejszym lub większym stopniu sprzyjających osiągnięciu głównego celu" - J. Stempowski, Nowe marzenia samotnego wędrowca, „Marchołt” 1935, nr 3, s. 449. W Literaturze w okresie wielkiej przebudowy z tego samego roku ujmował natomiast to zagadnienie następująco: „W atmosferze przebudowy powstały, jeszcze w okresie wielkiej wojny, hierarchie wartości właściwe oblężonemu miastu, gdzie życie obywateli jest ściśle podporządkowane celom wojennym i nikomu nie wolno oddawać się rozrywkom. Wreszcie w atmosferze chaotycznego budownictwa nastąpiło pomieszanie wartości użytkowych i ostatecznych" - idem, Szkice literackie, t. 1. Chimera jako zwierze pociagowe. 1926-1941, Warszawa 2001, s. 235.

${ }^{14}$ Zob. M. Krakowiak, „Historia zerwana z łańcucha”, czyli katastrofizm Jerzego Stempowskiego, „Ruch Literacki” 1994, z. 1-2.

${ }^{15}$ K. Wierzyński, Poezje, Lublin 1990, s. 178. 
Dobitnie widać więc, że generalizowanie w przypadku świadectw literackich na nic się zdaje.

W czasach gdy literatom o coś ważnego chodziło, kiedy formułowali programy integrujące i separujące zarazem, łatwiej było — także im samym — pomijać niuanse i niejednoznaczności. Łatwiej i czytelniej było odnosić się do schematów i schematy tworzyć (mimo wszystko!). Myślę tutaj oczywiście o czasie okupacji i o przykładzie najspójniejszej i najradykalniejszej grupy Sztuka i Naród (zbliżyliśmy się tym samym do momentu, gdy pojęcia z hasła „Bóg - Honor - Ojczyzna” zaczęły funkcjonować jako jednia). Tworzący pismo i środowisko ideowe konspiracyjni twórcy i żołnierze nie dostrzegali w poezji najpopularniejszych autorów międzywojnia niczego wartościowego:

Trzeba postawić wreszcie jasno i powiedzieć, że to bardzo ważne, że zasadnicze: poezja dwudziestolecia była w 3/4 twórczością obcą tej ziemi i duszy człowieka tej ziemi. W twórczości poetów takich jak Tuwim, Słonimski, Leśmian czytam ową ciągłą troskę o „poprawność”, polską poprawność wewnętrzną. Skamander to nie tylko styl poetycki, to pogląd na życie. W skrócie powiedzieć można, że życie to jest sobiepańskie, poeta dochodzi z nim do porozumienia na podstawie etyki wypracowanej... w wierszu, ot, aby było ładnie. Mamy więc ładne wiersze, brak nam wielkiej poezji ${ }^{16}$

— pisał w programowym artykule Juz nie potrzebujemy Tadeusz Gajcy.

Uderzający jest w publicystyce autorów Sztuki i Narodu ów bezkompromisowy ton. Czytywali oni na powrót Norwida i zdania zaczerpnięte z jego Promethidiona: „Narodowy artysta organizuje wyobraźnię, jak na przykład polityk narodowy organizuje siły stanu..."17 oraz „Tylko sztuce pojętej w całej swojej prawdzie i powadze Polak dzisiaj poświęcić może życie"18 czynili mottem własnego życia. W swoim patriotyzmie byli heroiczni. Na przekór sytuacji zewnętrznej tworzyli projekty odbudowania potęgi polskiej kultury. Porażająco brzmią słowa Andrzeja Trzebińskiego z tekstu $W$ klimacie kultury imperialnej:

Kultury prawdziwie silne, mające świadomość własnej siły, nie poprzestają nigdy jedynie na organizowaniu swego kulturalnego mitu. Wola kultur silnych nie zużywa się i nie niszczy wytwarzaniem i stawianiem przed sumieniem człowieka coraz to nowych imperatywów. Imperatywy i mity kulturalne - o tym trzeba pamiętać — najłatwiej powstają w zamroczeniu, jako emanacja upojnej wyobraźni. Najłatwiej dlatego, ponieważ w owym zamroczeniu czy upojeniach tracą charakter trudnych i niebezpiecznych zadań, a plączą się i utożsamiają chętnie z dowolnie widzianą i nierealnie ocenianą rzeczywistością istotną. [...] Realizm kultury jest w równej mierze kwestią mocnej i dobrej woli co mit. Kultura prawdziwie silna zdobywa się, obok wysiłku wytworzenia mitu, na wysiłek ogarnięcia, swego rodzaju imperialistycznego podboju przez świadomość kulturalną, pełnej, najbardziej pełnej rzeczywistości. Dopiero te dwa momenty: mit i realizm, związane ze sobą strukturalnie, obdarzają kulturę męską równowagą, dojrzałością i dyscypliną ${ }^{19}$.

${ }^{16}$ T. Gajcy, Już nie potrzebujemy, [w:] Konspiracyjna publicystyka literacka 1940-1944. Antologia, oprac. i wstęp. Z. Jastrzębski, Kraków 1973, s. 129.

17 C.K. Norwid, Pisma wybrane, t. 2. Poematy, Warszawa 1983, s. 315.

18 Ibidem, s. 320.

${ }^{19}$ A. Trzebiński, Polska fantastyczna. Szkice. Dramat. Wiersze, zeb., oprac., posł. M. Urbanowski, Łomianki 2017, s. 58-59. 
Maksymalizm etyczny i intelektualny wraz z gorączkowością wywodu wyraźnie świadczą o patronacie Stanisława Brzozowskiego. Taki model służenia ojczyźnie, model patriotyzmu, wydaje się nadludzki, heroiczny właśnie i elitarny, gdyż niemożliwy do podjęcia, a nawet zrozumienia przez wszystkich.

Twórców Sztuki i Narodu łatwo przyjdzie - schematyzując oczywiście zagadnienie — uznać za wcielenie ideału patrioty, oddającego „Ojczyźnie wszystko prócz miłości Boga najwyższego i honoru", bohaterskiego i niezłomnego. Owszem, ale świadectwa pisane urozmaicają i ten monolit. We wspomnieniach Stanisława Zadrożnego, oficera biorącego udział w kampanii wrześniowej, a potem w powstaniu warszawskim, zachowała się relacja ze spotkania z Tadeuszem Gajcym 2 sierpnia 1944 roku. Z ust Gajcego padły wtedy słowa:

Czy może mi pan powiedzieć, jak trzeba... jak można pokonać strach... jak trzeba umierać? Bo ja się boję. I dlatego pytam, co trzeba zrobić, by jeśli trzeba zginąć, to tak, żeby nikt nie widział strachu $^{20}$.

Poeta, żołnierz AK, który miał zginąć dwa tygodnie później, przyznał się do odczuwania strachu. Wraz z nim zginął na barykadzie Leon Zdzisław Stroiński. On z kolei pozostawił po sobie zapis myśli bluźnierczej:

Z Hiobów w Konrady

Szaleni przez wielkość.

Krzywd męki śmierci najświętszą pożogę

i rozpacz zemsty krzyczącej o krew -

rzucamy Polskę w twarz zimnego Boga -

obelgę ${ }^{21}$.

Czy są to skazy na idealnych pomnikach cnotliwych bohaterów? Przeciwnie! Dzięki wskazanym rozdarciom i zawahaniom owe pomniki stają się jeszcze doskonalsze, bo dramatycznie ludzkie (pod warunkiem oczywiście, że obserwatorzy/czytelnicy współcześni zdobędą się na indywidualny wysiłek umysłowy).

Pokolenie twórców wojennych dostarczyło obfitego materiału egzemplarycznego rozważaniom o triadzie „Bóg - Honor - Ojczyzna”. W początkowej części niniejszego artykułu wspomniałam, że wespół z hasłem „Bóg — Honor - Ojczyzna" polskie imaginarium konstytuuje także inna aksjologiczna triada: „wolność — równość — braterstwo”. Wartości współtworzące poszczególne hasła częstokroć się przenikają i uzupełniają na polskiej mapie fantazmatów. Szczególnie jasne wydaje się to właśnie podczas analizowania świadectw patriotycznych z czasów walk o niepodległość, a więc o wolność przecież. Zanim sięgniemy po konkretny przykład, warto odnotować, że podobnie jak hasło „Bóg — Honor — Ojczyzna” triada „wolność — równość — braterstwo” ma proweniencję fran-

${ }^{20}$ Cyt. za: W. Bartoszewski, Dni walczacej Stolicy. Kronika Powstania Warszawskiego, Warszawa 2004, s. 129.

${ }^{21}$ L.Z. Stroiński, *** [Po huraganach szarż...], [w:] Z rodu Anhellich. Liryka pokolenia wojennego, wyb., oprac., przedm. i not. biograf. S. Stabro, Wrocław 1991, s. 196. 
cuską, sięgającą doby rewolucji, kiedy to w końcu czerwca 1793 roku pojawiła i upowszechniła pełna wersja zawołania: Liberté, egalité, fraternité ou la Mort!

Po raz kolejny Polacy szybko się utożsamili z francuskim hasłem i uznali za własne, wypełniając je treściami odnoszącymi się do własnych doświadczeń. Uniwersalny, mitogenny walor slogan zyskiwał w postaci skróconej, z pominięciem przeciwstawnego, wywołującego niepokój, drugiego członu. Bezcenne wręcz dla narodowej mitografii są natomiast chwalebne przykłady romantycznych walk ,za wolność waszą i naszą" i bratania się z — podobnie jak my — ciemiężonymi. Podobnie również jak „Bóg — Honor — Ojczyzna” hasło „,wolność — równość — braterstwo" szczególnie wypełniło się bogactwem znaczeń dzięki pokoleniu wojennemu. Wszelkie wątpliwości rozwieje lektura ascetycznych Prób świadectwa Jana Strzeleckiego, w których czytamy na przykład:

Myśmy wiedzieli, czym jest braterstwo. Braterstwo oznacza utożsamienie się z kimś drugim, nieoddzielanie jego losu od swojego; więcej nawet — widzenie jego niebezpieczeństwa wyraźniej niż swego, doznanie, że jego śmierć jest trudniejsza do przeżycia niż własna. Braterstwo jest łatwością przekraczania tych granic, które filozofowie głoszący samotność człowieka uznają za nieprzekraczalne, za linię, za którą jest już tylko milczenie lub powrót własnego głosu. Tkwiliśmy głęboko wewnątrz słowa „my”, słowa, w którym fenomenologowie widzą wyraz oznaczający szczególną jakość doświadczenia, jakość kształtującą odbiór świata, nadającą nam inny wymiar istnienia ${ }^{22}$.

Głos Strzeleckiego (rocznik 1919) zasługuje tu na baczną uwagę. Zaświadcza o istnieniu tak głęboko humanistycznej postawy, tak bezkompromisowej wierności drugiemu człowiekowi — bratu — w sytuacjach granicznych ${ }^{23}$, że staje się wielce pożądanym przez wielu przykładem. Stąd już krok tylko do przypisywania sobie nie swoich zasług, do uzurpowania sobie prawa zaliczania siebie, jakichś „nas” - Polaków, a więc następców, potomków Kolumbów — do grona wyznawców i obrońców wartości, tak ,z definicji”, w sytuacji gdy nikt nie powie „sprawdzam”. Wygodniej (dla bezmyślnych) będzie więc pominąc inne słowa Strzeleckiego, na przykład te dotyczące egzystencji w obozie koncentracyjnym:

Tortura, którą wszczynać można było w każdej chwili i stopniować bez granic, była najwymowniejszym dowodem tego, że człowiek nie jest człowiekowi bratem. Ale dowód ten nie był dowodem zamkniętym nawet w porządku faktów, cóż dopiero w porządku wartości. Właśnie tam, za bramą, przeciwdziałał jego wymowie każdy karany śmiercią akt braterstwa, każdy akt, w którym człowiek w sytuacji najwyższego zagrożenia uznawał w potrzebie drugiego człowieka najoczywistszą pobudkę działania. Doświadczenie kruchości tych prawd współistniało więc z doświadczeniem ich najgłębszego w człowieku zakorzenienia ${ }^{24}$.

Jak zawsze, gdy wskazywana jest „kruchość prawd”, prezentowane racje stają się zgoła nieprzydatne do praktycznego budowania wspólnotowej mitografii,

22 J. Strzelecki, Ślady tożsamości, Warszawa 1989, s. 145.

${ }^{23}$ Strzelecki pisał: „Jeśli pojęcie sytuacji granicznej było jednym z naszych pojęć, to nie dlatego, żeśmy czytali Jaspersa, tylko dlatego, żeśmy żyli trwale w sytuacjach, którym cechy graniczności istotnie przysługiwały" - ibidem, s. 165.

${ }^{24}$ Ibidem, s. 173. 
będąc nazbyt wymagającymi indywidualnego rozważenia, a więc kłopotliwymi. Odnotowawszy ich istnienie, poprzestańmy na tym.

Ojczyzna. Wolność Ojczyzny. Wierność zasadom. Braterstwo walki. Zauważmy, że wszystkie te elementy stanowią swoistą kompilację obu triad wartości: „Bóg - Honor - Ojczyzna” i „wolność — równość — braterstwo”. Współtworzą one - przeważający w polskiej kulturze — model patriotyzmu ofiarniczego, heroicznego, angażującego ostre kategorie etyczne i estetyczne typu wzniosłość i tragizm. Taka postawa, taki typ zobowiązania był, jak wiemy, zrozumiały i naturalny dla uczestników bitew, wojen, prześladowań.

Zobaczyliśmy jednak, że właśnie sami świadkowie i uczestnicy wspomnianych wydarzeń dalecy byli od wręcz nieludzkiej koturnowości, skąd jakże blisko do... niestosowności, a nawet śmieszności. Na marginesie trzeba zaznaczyć, że podobny stosunek do świata, podobną tendencję do indywidualnego przełamywania schematu można było zaobserwować w postawach twórców beztrosko witających niepodległość: manifestowanie radości z życia nie oznaczało tylko bezrefleksyjnego egoizmu i negowania wspólnej tożsamości. Podobne „wyjątki” odrzuca jednak thum i sterujący nim ,inżynierowie dusz”, czyli demagodzy.

Spragnieni ładu pojęciowego i jasnych reguł organizowania życia ludzie współcześni pozornie chętniej identyfikują się z modelem patriotyzmu „na serio”, patriotyzmu ofiarniczego, zdecydowanie bardziej „malowniczego” przedstawieniowo aniżeli model minimalistyczny — społecznikowsko-ekonomiczny. Przypominane są z upodobaniem uproszczone często historie bohaterów, niezłomnych w wierze i nieodczuwających strachu, przejmowane są ich symbole. Niestety, często czynione to jest w sposób nieprzemyślany, jak choćby w przypadku znaku Polski Walczącej, o którego obronę przed postponowaniem go przez głupców występowali w społecznej kampanii reklamowej powstańcy warszawscy. Tym niemniej taki właśnie - uproszczony i ułatwiony — model patriotyzmu ofiarniczego (zatem pseudoofiarniczego) wydaje się dziś najbardziej atrakcyjny.

Trudniej przychodzi zmierzyć się z modelem biegunowo przeciwstawnym, powstałym w wyniku znużenia tematyką narodowowyzwoleńczą, ale podawanym właśnie w sposób właściwy dzisiejszym zwolennikom tatuaży z kotwicą powstańczą i haseł typu „Nie dajmy zginąć poległym” lub „historia i religia Polski dla nas to rzecz święta, dla was liczy się angela i dzikie zwierzęta"25.

W dyskursie już nie ulicznym, ale intelektualnym za patronów obrazoburczego stosunku do narodowej tradycji mogą uchodzić Witold Gombrowicz i Sławomir Mrożek ${ }^{26}$. W wywiadzie opublikowanym w 1996 roku na łamach „Frondy”

${ }^{25}$ Slogan (pisownia oryginalna) z manifestacji utrwalonej na zdjęciu w tygodniku „Polityka” 2016, nr 35 .

${ }^{26} \mathrm{O}$ roli Mrożka w tworzeniu krytycznego modelu polskich mitów tożsamościowych zob. M. Krakowiak, Oblężenie: metafora i diagnoza, [w:] Oblężenie. Strategia pisarska - postrzeganie świata - motyw literacki, red. M. Krakowiak, Katowice 2014. 
to ich właśnie Jarosław Marek Rymkiewicz uznał za szyderców szerzących terror, mówiąc:

uznaniem wybitnych znawców naszej literatury cieszą się od lat pisarze w rodzaju Gombrowicza i Mrożka, a także spadkobiercy Gombrowicza i Witkacego. Ten, kto szydzi, ten, kto ironizuje, ten, kto się wygłupia, kto mówi dwuznacznie, kto nie mówi serio, jest ceniony wyżej, nawet znacznie wyżej od takiego, który stara się przemawiać poważnie. A taki, który przemówi poważnie, może zostać oskarżony o niestosowny patos. [...] Ale życie nie składa się tylko z rzeczy śmiesznych, składa się także z rzeczy poważnych ${ }^{27}$.

Zaiste, nie zawsze i nie o wszystkim da się, powinno się, uchodzi mówić ironicznie, niepoważnie, prześmiewczo. Czy wszakże sensowne będzie jednak wyłączenie z sumy polskich patriotów Gombrowicza, który napisał w 1957 roku w Dzienniku:

Polak z natury swojej jest Polakiem. Wobec czego, im bardziej Polak będzie sobą, tym bardziej będzie Polakiem. Jeśli Polska nie pozwala mu na swobodne myślenie i czucie, to znaczy, że Polska nie pozwala mu być w pełni sobą, czyli — w pełni Polakiem. [...] Ta polskość spontaniczna i naturalna, zawarta w każdym z nas, doznaje wielkiego uszczerbku, ponieważ wyzbyliśmy się pełnej szczerości i swobody ducha na rzecz mocy zbiorowej — której nie uzyskaliśmy ponieważ jest nieosiągalna. [...] Chciałem po prostu, aby Polak przestał być wyłącznie wytworem życia zbiorowego — i „dla” życia zbiorowego. Chciałem go uzupełnić. Zalegalizować jego drugi biegun — biegun życia indywidualnego - i rozpiąć go między tymi dwoma biegunami ${ }^{28}$.

Owo różnicowanie, wyłączanie innych niż ,ja” spośród „nas” jest arcypolskie — chciałoby się powiedzieć. Sądzę jednak, że ów bezmyślny model patriotyzmu, nakazujący obrzucać anatemą przedstawicieli myślenia o ojczyźnie w sposób krytyczny albo „,minimalistyczny” (słynne płacenie podatków), ma charakter uniwersalny — występuje ponadnarodowo.

\section{Bibliografia}

Bartoszewski W., Dni walczacej Stolicy. Kronika Powstania Warszawskiego, Warszawa 2004.

Gombrowicz W., Dziennik (1957-1961), Paryż 1962.

Heller M., Ostateczne wyjaśnienia wszechświata, Kraków 2008.

Konspiracyjna publicystyka literacka 1940-1944. Antologia, oprac. i wstęp Z. Jastrzębski, Kraków 1973.

Krakowiak M., „Historia zerwana z łańcucha”, czyli katastrofizm Jerzego Stempowskiego, „Ruch Literacki" 1994, z. 1-2.

Krakowiak M., Oblężenie: metafora i diagnoza, [w:] Oblężenie. Strategia pisarska — postrzeganie świata - motyw literacki, red. M. Krakowiak, Katowice 2014.

Lechoń J., Poezje, Wrocław-Warszawa-Kraków 1990.

Leder A., Prześniona rewolucja. Ćwiczenie z logiki historycznej, Warszawa 2014.

Mikołejko Z., Plutony różańca, [rozm. A. Sowa], „Polityka” 2018, nr 40.

Molenda J., Mity polskie, Warszawa 2016.

27 J.M. Rymkiewicz, Terror szyderców. Rozmawiają T. Majeran i D. Suska, „Fronda” 1996, nr 6.

${ }^{28}$ W. Gombrowicz, Dziennik (1957-1961), Paryż 1962, s. 23-24. 
Myśliwski W., Wbrew rozsądkowi i nadziei. Z Wiesławem Myśliwskim rozmawia M. Nogaś, „Wyborcza. Książki. Magazyn do czytania”, listopad 2018.

Napiórkowski M., Mitologia wspótczesna. Relacje o poczynaniach i przygodach krajowców zamieszkatych globalnej wiosce, Warszawa 2013.

Norwid C.K., Memoriat o młodej emigracji. W odpowiedzi na zapytanie szanownego p. Gatęzowskiego, [w:] idem, Pisma wybrane, t. 4. Proza, Warszawa 1983.

Norwid C.K., Pisma wybrane, t. 2. Poematy, Warszawa 1983.

Rymkiewicz J.M., Terror szyderców. Rozmawiają T. Majeran i D. Suska, „Fronda” 1996, nr 6.

Słowacki J., Wiersze i poematy, Warszawa 1988.

Stempowski J., Nowe marzenia samotnego wędrowca, „Marchołt” 1935, $\mathrm{nr} 3$.

Stempowski J., Szkice literackie, t. 1. Chimera jako zwierze pociagowe. 1926-1941, Warszawa 2001.

Stróżewski W., Patriotyzm, czyli przemienieni kołodzieje, „Tygodnik Powszechny”, Wydanie specjalne” 2018, nr 2. Prwdr. „Tygodnik Powszechny” 2006, nr 27.

Strzelecki J., Ślady tożsamości, Warszawa 1989.

Trzebiński A., Polska fantastyczna. Szkice. Dramat. Wiersze, zeb., oprac., posł. M. Urbanowski, Łomianki 2017.

Wierzyński K., Poezje, Lublin 1990.

Z rodu Anhellich. Liryka pokolenia wojennego, wyb., oprac., przedm., noty biograf. S. Stabro, Wrocław 1991.

\title{
The sum or the difference, or, who is a Polish patriot? Divagations about contemporary cultural myths
}

\author{
Summary
}

The first part of the question in the title refers to two slogans that are simultaneously two axiological triads; these triads (God-Honour-Home Country and Freedom-Equality-Brotherhood) were previously the subject of my investigations. It looks like they constitute the basic components of Polish contemporary imagination, containing an important symbol for Polish imagination and phenomena, symptomatic of emotions and ethics. One should note the meaning of these values' separation. The article shows the initial contest of both slogans as well their importance and transformed contemporary meaning. Using as an example the selected texts of literature, both critical and journalistic, the paradox of Polish patriotism has been presented, where "everybody" identifies with and at the same time excludes "those different than me." Attention was paid to the domination of the sacrifice model of patriotism in Polish culture, in opposition to other models: critical and "minimalistic" ones.

Keywords: patriotism, axiology, community, exclusion, myth 